\title{
THE ENFORCEMENT OF RESALE PRICE MAINTENANCE
}

Proponents of resale price maintenance ${ }^{1}$ are presently seeking to revitalize "fair trade" through federal legislation, ${ }^{2}$ and thus to overcome a recent series of judicial setbacks. Federal courts have held the application of state fair trade statutes to interstate mail order sales consummated in non-fair-trade areas beyond the scope of the McGuire Act, ${ }^{3}$ which immunizes state price maintenance legislation from the federal antitrust laws. ${ }^{4}$ And seventeen state courts

1. State resale price maintenance acts allow producers or distributors of goods which carry their trademark or trade name to contract with retailers to resell his goods at not less than a minimum resale price, and-through "nonsigner clauses" - to bind all rctailers to sell at not less than the stipulated price. In a minority of states, the producer may set the exact price. Note, 69 HARv. L. REv. 316 (1955) (giving detailed history).

2. See Hearings on H.R. 768, 1253, 2463, 2729, 3187, 5252 and 5602 Before the Honse Committee on Interstate and Foreign Commerce, 86th Cong., 1st Sess. 71 (1959) [hercinafter cited as 1959 Hearings]; Hearings on H.R. 10527, 10770, 10847, 11048, 11216, and 11264 Before a Subcomnittee of the House Committee on Interstate and Foreign Commerce, 85th Cong., 2d Sess. 676 (1958) [hereinafter cited as 1958 Hearings] ; N.Y. Times, May 26, 1958, p. 20, col. 5.

3. The leading case is General Elec. Co. v. Masters Mail Order Co., 244 F.2d 681 (2d Cir. 1957), which held that the defendant, in the District of Columbia, could sell fairtraded goods at cut prices by mail to buyers in fair-trade states. This case was a logical extension of Bissell Carpet Sweeper Co. v. Masters Mail Order Co., 240 F.2d 684 (4th Cir. 1957), which held that advertisement in Maryland of lower than fair-trade prices by a District of Columbia retailer was not in violation of the Maryland Fair Trade Act.

Another decision has proscribed a fair-trade agreement between a wholesaler and a manufacturer, competing in selling to retailers, as a horizontal agreement not exempted by the MicGuire Act. United States v. McKesson \& Robbins, Inc., 351 U.S. 305 (1956). This case has been criticized, however, as overreaching congressional intent by limiting the McGuire Act's application. Note, 67 YALE L.J. 1246, 1254-55 \& n.31 (1958). In Esso Standard Oil Co. v. Secatore's, Inc., 246 F.2d 17 (1st Cir. 1957) (gasoline refiner who sold to commercial fleets of vehicles in competition with a gasoline retailer), W(ckesson was followed and expanded in dictum. "[A]ny competition for customers is an absolute bar to price maintenance agreements between the competitors." Id. at 22. It would seem, however, that the McKesson rule as interpreted in Secatore's is limited in application. See General Elec. Co. v. Hess Bros., 155 F. Supp. 57, 63 (E.D. Pa. 1957) (plaintiffmanufacturer's discount sales to its employees for their own use does not make them competitors of defendant retailer within prohibition of the Sherman Act); Revlon, Inc. v. Wagonfeld, Trade Reg. Rep. (1959 Trade Cas.) II 69353 (N.Y. Sup. Ct. April 21, 1959) (plaintiff's own beauty salon, operated for demonstration purposes, did not bar right of plaintiff to fair trade because some retail sales were also made). H.R. 1253, 86th Cong., 1st Sess. § 2, p. 6, lines 14-18 (1959), would allow producers or distributors in the $M / C$ Kesson situation to fair trade their products if "such sales to retailers are made at the same prices he establishes for such wholesale distributors for comparable saleg, and ... he is not a wholesale distributor of products other than products which he manufactures."

4. 66 Stat. 631 (1952), 15 U.S.C. $\S 45$ (1958). The McGuire Act specifically validated nonsigner clauses. Earlier, the Miller-Tydings Act, 50 Stat. 693 (1937), 15 U.S.C. 
have effectively eliminated fair trade by ruling that the crucial "nonsigner" provisions - which bind all retailers to observe the fixed price whether or not they have so agreed-are violations of state constitutional guarantees, ${ }^{5}$ or have held resale price maintenance impliedly repealed by state antitrust laws. ${ }^{\circ}$ As a

\& 1 (1958) had exempted fair trade from the federal antitrust laws, but Schwegmann Bros. v. Calvert Distillers Corp., 341. U.S. 384 (1951), held Miller-Tydings inapplicable to nonsigner provisions.

Fair-trade pricing is contradictory to the general objective of the antitrust laws"promotion of competition in open markets." ATT'y GeN. NAT'L Cosss. Artitrust ReP. 1, 154 (1955) [hereinafter cited as ATT'y GEN. REP.] ; FTC, REPort ox REsale Price. MLAINTENANCE at LX-LXI (1945) [hereinafter cited as FTC REPORT]. If the fair-trade acts merely prevented ruinous competition among retailers, and thereby, in the long run, preserved competition, this might well be in keeping with antitrust policy. The fair-trade laws go further, however, and prevent price competition among retailers selling fairtraded articles, establishing, in effect, horizontal agreements among retailers to sell at fixed prices. Ibid.

5. Union Carbide \& Carbon Corp. v. White River Distribs., Inc., 224 Ark. 558, 275 S.W.2d 455 (1955) (deprivation of due process): Olin Mathieson Chem. Corp. v. Francis, 134 Colo. 160, 301 P.2d 139 (1956) (deprivation of due process and improper delegation of police power); Seagram-Distillers Corp. v. Ben Greene, Inc., 54 So. 2d 235 (Fla. 1951) ; Cox v. General Elec. Co., 21.1 Ga. 286, 85 S.E.2d 514 (1955) (due process); Bargain Barn, Inc. v. Arvin Indus., Inc., 1955 Trade Cas. 70463 (Ind. Super. Ct.) (in derogation of Indiana constitution); Quality Oil Co. v. E. I. du Pont de Nemours \& Co., 182 Kan. 488, 322 P.2d 731 (1958) (improper delegation of legislative power); General Elec. Co. v. American Buyers Co-op., 316 S.W.2d 354 (Ky. 1958) (due process); Dr. G. H. Tichenor Antiseptic Co. v. Schwegmann Bros. Giant Supermarkets, 231 La. 51, 90 So. 2d 343 (1956) (improper delegation); Shakespeare Co. v. Lippman's Tool Shop Sporting Goods Co., 334 Mich. 109, 54 N.W.2d 268 (1952) (due process); MreGraw Elec. Co. v. Lewis \& Smith Drug Co., 159 Neb. 703, 6S N.W.2d 608 (1955) (due proeess); Skaggs Drug Center v. General Elec. Co., 63 N.AT. 215, 315 P.2d 967 (1957) (improper exercise of police power); Union Carbide \& Carbon Corp. v. Bargain Fair, Inc. 167 Ohio St. 182, 147 N.E.2d 481 (1958) (improper exercise of police power); General Elec. Co. v. Wahle, 207 Ore. 302, 296 P.2d 635 (1956) (improper delegation of legislative power; due process); Rogers-Kent, Inc. v. Westinghouse Elec. Corp., 1955 Trade Cas. 70481 (S.C. Richland County Ct.) (alternative holding) (due process); Genera! Elec. Co. v. Thrifty Sales, Inc., 5 Utah 2d 326, 301 P.2d 741 (1956) (conflict with antitrust section of Utah constitution); General Elec. Co. v. A. Dandy Appliance Co., 103 S.E.2d 310 (W. Va. 1958) (improper exercise of police power).

In Arizona, however, a decision of a lower court holding a nonsigner clause unconstitutional has been reversed. General Elec. Co. v. Telco Supply Co., 84 Ariz. 132, 325 P.2d 394 (1958), reversing 1956 Trade Cas. 72212 (Ariz. Super. Ct.).

6. Benrus Watch Co. v. Kirsch, 198 Va. 94, 92 S.E.2d 384 (1956).

A federal district court has held that the Hawaii Fair Trade Act is in conflict with $\S 3$ of the Sherman Act, which proscribes restraint of territorial trade, and that the Miller-Tydings and McGuire Acts are operative only with respect to Sherman Act §1. Sunbeam Corp. v. Gem Jewelry Co., 157 F. Supp. 838 (D. Hawaii 1957). But the Supreme Court of Hawaii has held that the territorial fair trade act was exempted. Johnson \& Johnson, Inc. v. G.E.II. Sundries Co., Trade Reg. Rep. (1959 Trade Cas.) \69253 (Hawaii Sup. Ct. Jan. 16, 1959), reversing 1958 Trade Cas. 73751 (Hawaii Cir. Ct.). The question of whether the McGuire Act exempts the Hawaiian Fair Trade Act from the Sherman Act is a federal question because it involves interpretation of a federal 
result, fair trade protection is available in only twenty-nine states, ${ }^{7}$ and inapplicable, even there, to mail orders from other jurisdictions. Contemporaneously, abandonment by several leading brand-name producers in what were formerly "fair trade industries"8 has further restricted fair trade coverage." Moreover, mail order merchandising ${ }^{10}$ has grown in importance, and large chains and discount houses-retailers who have generally chosen to ignore fair trade and seek profits through a larger volume of cut-price sales-have been propelled into increasing preeminence. ${ }^{11}$

The proposed federal legislation-H.R. $1253^{12}$-attempts to strengthen fair trade by extending coverage to all states and, concomitantly, to all mail order houses. ${ }^{13}$ The bill would create a right of action in federal court, irrespective of diversity of citizenship, to enforce adherence to the manufacturer's stipu-

statute. Gully v. First Nat'l Bank, 299 U.S. 109 (1936). Therefore the decision of the Hawaii Supreme Court is not binding upon the federal courts. Maternally Yours, Inc. v. Your Maternity Shop, Inc., 234 F.2d 538, 540-41 n.1 (2d Cir. 1956); Sunbeam Corp. v. Gem Jewelry Co., supra at 840 . Nonetheless, it would seem correct to say that the Hawaiian Act retains its force, since the grounds for the federal decision-Hawaii's territorial status-became invalid with Hawaii's entrance into the Union. See Act of March 18, 1959 , No. $86-3,73$ Stat. 4.

7. That is, all states other than the seventeen which have eliminated fair trade, see notes 5-6 supra, and Missouri, Vermont, Texas and Alaska, which have never enacted resale price maintenance.

8. "Fair-trade industries" refers to those in which an appreciable percentage of the goods are fair traded, e.g., drugs, electrical appliances, cameras, cosmetics, books, sporting equipment, and alcoholic beverages. Fulda, Resale Price Maintentance, 21 U. Cur. L. Rev. 175,179 (1954). While less than $10 \%$ of all retail goods are fair traded, 1958 Hearings 43,105 , and the percentage of fair trading manufacturers is small even in the above mentioned industries, 1958 Hearings 345 , the manufacturers who do fair trade are usually among the largest in their industry. 1958 Hearings 609.

9. The General Electric Co., the Sunbeam Corp. and the Toastmaster division of McGraw-Edison, Inc., leading enforcers of fair trade, have all abandoned price maintenance. They were followed by the Ronson Corp., the Royal McBee Corp., and other appliance manufacturers. The Westinghouse Corp. had dropped fair trade two years earlier. N.Y. Times, March 2, 1958, \& 3, p. 1, col. 1; 1958 Hearings 203. 'The fceling was expressed that the hostile attitude of the courts made any attempts at fair trade enforccment futile. Statement of the General Electric Co., id. at 319; Statement of Sunbeam Corp., id. at $279-80$.

10. See N.Y. Times, May 10,1.959, $\S 3$, p. 1, col. 7 (catalog sales of Montgomery Ward, Sears Roebuck and Spiegel, Inc.-three of the nation's largest mail order houses -reached $\$ 1,481,000,000$ in 1958) ; N.Y. Times, June 12, 1959, p. 41, col. 2 (sales of these three mail order firms $13.2 \%$ ahead of 1958 in the first five months).

11. See 1957 Dep't of Comaerce Ann. Retall TrAde Rep. 5; Revolution in Ratail Selling, U.S. News \& World Report, June 20, 1958, p. 48; Fortune, April 1958, pp. 106, 108.

12. 86th Cong., 1st Sess. (1959). The House Committee on Interstate and Forcign Commerce approved the bill by a vote of 20-9 on May 14, 1959. Wall Street Journal, May 15, 1959, p. 1, col. 4.

13. H.R. 1253, 86th Cong., 1st Sess. § 2, pp. 5-7 (1959). 
lated or minimum retail price. ${ }^{14}$ If the manufacturer's output is "in commerce" and in "free and open competition with merchandise of the same general class produced by others,"15 all retailers with "actual notice" of the fair trade price would be bound to observe that price. ${ }^{16}$ The requirement of actual notice, which supplants "nonsigner" clauses, ${ }^{17}$ could be met simply by marking the price on the goods or their container. ${ }^{18}$ But, the proposed federal legislation does not create new remedies or reverse the case law which has restricted the enforcement of existing state statutes. The potential impact of the federal bill must therefore be assessed by examination of the success of attempts to enforce the state fair trade laws. If possible plaintiffs-retailers, retail associations, manufacturers-can not, or will not, enforce fair trade, the federal bill will prove no more effective than present state statutes.

\section{Fair Trade Plaintifis \\ The Retailer}

Retailing was once a generally small-scale enterprise, often characterized by sheltered market areas, tantamount to territorial oligopolies or monopolies, in which the storekeeper was substantially insulated from price competition.10 But modern transportation and communication made it possible for a single outlet to cater to customers over a broad geographic area. Increased volume selling, resulting in economies of larger scale operation and lower per-unit overhead costs, were thus realized by some retailers-notably the discount houses, mail order firms, and large chains. ${ }^{20}$ In addition, many larger retailers minimized investment in plant and equipment and lowered variable costs by cutting personnel as well as credit and delivery services. ${ }^{21}$ The advantages of larger scale selling and low overhead operation are particularly marked in the case of relatively high-cost consumer durables; buyers may be willing to search further and undergo greater inconvenience to obtain bargains in such items.

Free competition in the consumer market tends to benefit these larger scale

14. H.R. 1253 , supra note $13, \S 2$, at 7 , lines $6-24$. The bill would allow a manufacturer to fix either an exact price or a minimum price. H.R. 1253, sipro, $\S 2$, at 6 , lines $1-2$.

15. H.R. 1253, stupra note $13, \S 2$ at 6 , lines $4-5$.

16. H.R. 1253, supra note $13, \S 2$ at 6 , lines 1-18.

17. The proposed bill forbids all retailers with notice of a "stipulated" (exact) price to sell at a different price, or with notice of a minimum price to sell at a lower price. H.R. 1253, supra note 13, $\S 2$ at 6 , lines 19-24, through p. 7, lines 1-5.

18. See H.R. 1253, supra note $13, \S 2$ at 5 , lines $16-18$.

19. Yadey, The Econonics of Resale Price Miaintenance 73-91 (1954) [hereinafter cited as Yansey]; Grether, Price Control Under Fatr Trade Lecislation 227 29 (1939) [hereinafter cited as GreTHER].

20. See Stocking \& Watrins, Moxopoly and Free Enterprise 315-16 (1951) [hereinafter cited as Stocking \& WatkINS]; Y AMrEy 89; Gretner 229-30.

21. See Stocking \& Watkins 327-29; Yasrex 6-8, 73-74; Grether 241-51. 
retailers, and they have by and large opposed fair trade ${ }^{22}$ and sought to maximize profits through increased volume sales. But many smaller dealers, threatened by displacement, look to fair trade for protection from price competition. ${ }^{23}$ They were the principal backers of the state fair trade acts, ${ }^{24}$ as well as the Miller-Tydings and McGuire Acts. ${ }^{25}$ An effectively enforced system of resale price maintenance may shelter smaller dealers from technological shortcomings.

Nevertheless, the fair trade retailers, notwithstanding their enthusiasm, usually have been unwilling or unable to enforce state acts. ${ }^{20}$ This can partly be attributed to the inadequacy of available remedies-a factor which also contributes to lack of enforcement by manufacturers. ${ }^{27}$ But other obstacles to enforcement, which especially handicap the marginally profitable retailer (who normally is the party most interested in price maintenance), may be of equal importance. The highest legal roadblock to the small retailer's success is a restricted judicial construction of the criteria for standing to sue. The state acts normally provide that "any person damaged" by the illegal price cutting may bring suit, ${ }^{28}$ and the courts have properly interpreted this provision to bar actions by retailers not in competition with the price cutter. But the judiciary has taken a limited view of the scope of the geographic area and the range of products within which retailers are held to be "in competition." As regards geographic area, it has been held, for example, that package stores less than four miles apart were not in close enough proximity. ${ }^{20}$ With respect to products, retailers have been held to be competing only when both are selling the same brand. ${ }^{30}$

22. See sources cited note 21 supra.

23. See Stocking \& Watkins 315-16; Yaney 89; Grethen 229-30.

24. 1958 Hearings 202, 204, 631; MUND, GovERNMENT AND BusINEss 434, 436-37, 440

(1950) [hereinafter cited as MuND]; FTC REPORT Xxvir, Xxxil, LIv, 10, 52-58, 142-56.

25. See sources cited note 24 supra; note 4 supra and accompanying text.

Prior to Miller-Tydings, Congress had refused to enact several fair trade bills. Sce FTC REPORT 39-42.

26. Fewer than $10 \%$ of the cases summarized in 1 TrAde Reg. Rep. Iff $3015-460$ (Cum. 1959) involve retailers as plaintiffs.

27. See notes 106-43 infra and accompanying text.

28. Fair trade acts generally make violations actionable only by "persons damaged." New Jersey, Pennsylvania, and Ohio are the exceptions. See 1 Trade Reg. Rer. If 3330 (Cum. 1959). The New Jersey act provides for suit by the producer or distributor of the commodity or by any retailer selling such commodity at not less than the fair trade pricc. N.J. Stat. Ann. § 56:4-3 (Supp. 1958). The Pennsylvania act allows suit by the vendor, buyer, or purchaser of the commodity. Penn. Stat. AnN. tit. 73, \& 8 (1953). And the Ohio act provides for suit by any other retailer of the commodity or at the suit of any other persons damaged thereby, including the producer of the commodity. Onio REv. COde ANn. § 1333.08 (Page 1953).

29. Weisstein v. Peters Corbyan Liquor Store, 104 N.Y.L.J. 83 (Sup. Ct. 1940); sec Weil, Inc. v. Gimbel Bros., 101. N.Y.L.J. 1621 (Sup. Ct. 1939). But cf. Friedman v. Peller, 1950-1951 Trade Cas. 64300 (N.Y. Sup. Ct. 1951) (plaintiff declared to be in price cutter's "general vicinity").

30. LePage v. Automobile Club, Inc., 17 N.Y.S.2d 568 (Sup. Ct. 1940); Eton Chem- 
The enforcement of maintained prices by retailers is also deterred by the expenses incident to suits against price cutters. In addition to legal fees, the acquisition of sufficient evidence to convince a court of alleged violations is a significant expense. ${ }^{31}$ Cautious selling by a price cutter who fears litigation may require that the enforcer employ professional shoppers to uncover necessary facts. ${ }^{32}$ And these costs can seldom be recouped through successful suit, since an injunction and not damages is the usual remedy. ${ }^{33}$ Even if the enforcer gains an injunction, additional costs may be necessary to police the decree and bring possible contempt actions. The enforcer is further handicapped; many fair-trade violators are relatively prosperous retailers, often better able to afford qualified counsel and prolonged litigation. ${ }^{34}$ Rather than undertake costly litigation, many retailers may simply discontinue the product.

ists, Inc. v. Sussman, 278 App. Div. 899, 104 N.Y.S.2d 902 (1951). Thus, actions by retailers selling different brands have been denied. But state statutes and the MrcGuire Act, in granting the manufacturer the privilege to fair trade, require that his product be "in free and open competition with other products of the same general class." This view that competition for the purposes of fair trade would encompass all brands of products of the same "general class" conforms to economic reality and to the interpretation of product markets in other branches of trade regulation law. See Comment, 68 YaLE L.J. 1627,1632 n.24 (1959). So long as products $A$ and $B$ "have reasonable interchangeability," see United States v. E. I. du Pont de Nemours \& Co., 351 U.S. 377, 404 (1956), if the price of $A$ is cut in violation of the fair-trade statutes, sellers of $B$ will lose buyers and will be injured by the price cutting. Therefore, not only the sellers of $A$, but also the sellers of $B$ could, if the standing-to-sue requirement were realistically construed, be given a right of action against the price cutter.

31. The price cutter may keep no record of his sales, may not give sales receipts, and may be careful to whom he sells at the cut price. See 1958 Hearings 250; Brief for Appellee, pp. 6, A1-4, A34-35, Sunbeam Corp. v. Golden Rule Appliance Co., 252 F.2d 467 (2d Cir. 1958). In Revlon, Inc. v. Wagonfeld, Trade Reg. Rep. (1959 Trade Cas.) If 69353 (N.Y. Sup. Ct. April 21, 1959), costs of investigating infractions by each of cight retailers averaged $\$ 650$ per defendant.

32. See 1958 Hearings 609, 663; Calvert Distillers Corp. v. Feldman, 101 N.Y.L.J. 2930 (N.Y. Sup. Ct. 1939) (court stated that using hired shoppers was practically the only method of obtaining evidence). Other cases in which evidence was obtzined by shoppers are Sunbeam Corp. v. J. Eis \& Sons Appliances, 1956 Trade Cas. 71693 (S.D. N.Y.) ; McGraw Elec. Co. v. Rosenberg, 1955 Trade Cas. 70630 (N.Y. Sup. Ct.).

33. See notes $106-43$ infra and accompanying text.

34. Price cutters have been able to relitigate any minor issue possibly constituting a defense. 1958 Hearings 280; cf. Fogel v. Bolet, 87 N.Y.S.2d 471 (Sup. Ct. 1949). Among the defenses that have been frequently raised are: The product is not in free and open competition with other products of the same general class, see, e.g., Revere Copper \& Brass, Inc. v. Economy Sales Co., 127 F. Supp. 739 (D. Conn. 1954); defendant merely leased space to independent concessionaire, see, c.g., Bulova Watch Co. v. Sattler's, Inc., 208 Misc. 257, 143 N.Y.S.2d 742 (Sup. Ct. 1955); discriminatory enforcement, see notes 113-16 infra and accompanying text; plaintiff is also a price cutter, see notes 111-12 infro and accompanying text; lack of standing to sue, see notes 28-30 supra and accompanying text; fair trade contract is illegal as a horizontal agreement, sce note 3 supra; Eli Lilly' \& Co. v. Rosenblum, 1957 Trade Cas. 72835 (N.Y. Sup. Ct) ; and meeting of competition, see, e.g., Upjohn Co. v. Liberty Drug Co., Trade Reg. Rep. (1959 Trade Cas.) If 69362 (S.D.N.Y. May 12, 1959). These are in addition to the statutory defenses of clos- 
Additionally, it is not certain that a system of flawlessly enforced resale price maintenance would protect smaller retailers or return customers to them. True, under fair trade the consumer could no longer save money by purchasing fair trade goods at the more distant or less accessible discount house or mail order concern, and would be inconvenienced by the additional effort. But fair trade, even at its optimum, only provides a means whereby the manufacturers can protect small retailers from price competition in fair traded products. Although no longer able to undersell his rivals in fair-traded products, the large-scale, low-overhead merchant can attract customers by setting a lower price for unbranded or non-fair-traded products, which differ only slightly if at all from fair-traded brands and are often produced by the same manufacturer. ${ }^{35}$ So long as production is reasonably competitive, price cutting retailers will have a continuing supply of non-fair-traded substitutes with which to compete with their higher priced competitors. Consumers might be increasingly willing to forego an advertised name in order to purchase the same or similar products at lower prices, especially in the case of high priced durables. And if the large-scale dealer can maintain a higher profit margin on non-fair-traded products than his smaller competitors, and/or lower costs on fair-traded goods through volume, he might be able to engage in more attractive promotion and services. While such dealers currently view price competition as their easiest route to profit maximization, they might be able successfully to wage service competition against competitors who have lower profit margins. Hence, fair trade may be little more than a temporary palliative for the ills of the smaller retailer and may not prevent the spread of technological obsolescence.

\section{The Retailers' Association}

Associations of retailers might offer a means of overcoming many of the barriers to individual enforcement of maintained prices. ${ }^{30}$ Use of specialized investigative and legal staffs would aid in the uncovering and obtaining of evidence concerning violations. ${ }^{37}$ Most important, expenditures could be distributed either among the membership at large or among those members who

ing out sales, sales of damaged or deteriorated goods, sales under court order and sales to eleemosynary and governmental institutions. See, e.g., N.Y. GEN. Bus. LAw \& 369. a(2). These statutory defenses would also be available under the proposed federal bill. See H.R. 1253, 86th Cong., 1st Sess., § 2, p. 8, lines 1-24, through p. 9, lines 1-10 (1959).

35. See note 57 infra.

36. There are about 3000 local and 100 national retail trade associations in the Unitcd States. All of the major fields of retailing are represented. Letter From Office of Technical Services, Trade Association Division, United States Department of Commerce, to the Yale Law Jourual, March 30, 1959, on file in Yale Law Library.

37. Many of the associations have fair-trade committees among whose functions is the searching out of violations, FTC REPORT 222-23, 240, 243-49, 375; GRETHER 344-48; Letter From Sumner Silver, Counsel, Central Massachusetts Retail Ass'n, Inc., to the Yale Law Journal, March 25, 1959, on file in Yale Law Library, as well as a legal staff which necessarily has daily legal contact with these problems, FTC REPORT 375, 401. 
are usually injured, and could be spread over several years. Periodic "enforcement dues" would be an inexpensive form of insurance premium for each member against the possibility of suddenly being forced to bear the expense of a suit. Joint action would also eliminate possible expenses of duplication stemming from a multiplicity of suits against a single violator.

One factor which may inhibit enforcement by associations of retailers is their potential failure to obtain standing to sue as a "person damaged."3s Although in the only case directly on point, a New York trial court ruled that an association whose members would have been entitled to relief had standing to enjoin a violator, ${ }^{39}$ the vitality of this decision is doubtful, in view of the general tendency to construe the requirement of standing narrowly. ${ }^{* 0}$ Courts are not often likely to allow an association, not pecuniarily damaged by the price cutting qua association, to bring an enforcement action."1

But if the association itself is unable to obtain standing, this should not prevent it from directing and financing litigation on behalf of individual re-

38. Cf. id. at 243.

39. Office Mach. Dealers Ass'n v. Tytell Typewriter Co., 1948-1949 Trade Cas. 62895 (N.Y. Sup. Ct. 1948). In Nassau \& Suffolk County Retail Hardware Ass'n v. KorretteHempstead, Inc., 1954 Trade Cas. 69509 (N.Y. Sup. Ct.), relief was denied beeause of defendant's allegations that the members of plaintiff association were themselves price cutters, with no discussion of the association's standing to sue. Bergen County Pharmaceutical Ass'n v. Barden, 1950-1951 Trade Cas. 64015 (N.J. Super. Ct. 1950) held that the association had no standing to sue because it was not a "producer or distributor of the commodity or a retailer selling such commodity" as required by the New Jersey Fair Trade Act. The Pennsylvania act would seem similarly to bar suit by a trade association. See note 28 supra. And in Iowa Pharmaceutical Ass'n v. Mray's Drug Stores, Inc., 229 Iowa 554, 294 N.W. 756 (1940), the association was disregarded and its members were treated as individual plaintiffs.

40. See notes 28-30 supra and accompanying text.

41. The Office Machine Dealers court, see note 39 supra, ignored the issue of whether the association as an entity was pecuniarily damaged by the price cutting. In considering a subsequent motion for the examination of witnesses, Office Miach. Dealers Ass'n v. Tytell Typewriter Co., 1948-1949 Trade Cas. 62911 (N.Y. Sup. Ct. 1949), the court held that the association itself had no rights and that the true plaintiffs were the individual members of the association. But this did not affect the previous ruling that the association had the right to sue; therefore it may be implied that the association was suing as an agent of the members rather than in its own corporate capacity. Since an association as an entity would not appear to be damaged by price cutting, it would not have standing to sue for vioiation of the fair trade acts, by their very terms. Sce note 28 supra. But see Maine Rev. Stat. Ann. ch. 183, § 4 (1954); N.H. Rev. Star. Axs. $\S 357: 4$ (1955) (damage need not be proved to obtain an injunction). A party claiming a right under a statute must bring himself within the purview of the act. E.g., Strand v. Village of Watson, 245 Minn. 414, 72 N.W.2d 609 (1955); Hennenfent v. Flath, 60 N.W.2d 533 (N.D. 1954).

Theoretically, however, the price cutter is not put to a disadvantage because a suit for injunction is brought by an association, assuming that there is a member who would have standing to sue. The limitations of the decree would be no different from those of a decree in favor of an individual plaintiff. See notes 111-37 infro and accompanying text. 
tailers serving as nominal plaintiffs. ${ }^{42}$ A New York trial court has upheld such a practice against a defense of conspiracy in restraint of trade. ${ }^{43}$ Nor should traditional rules against barratry and maintenance ${ }^{44}$ bar such suits. So long as the objective of the party financing the litigation is not financial speculation or harassment of the opposing party, most state courts have sharply limited barratry and maintenance prohibitions, ${ }^{45}$ and comparable group financing of litigation is widely practiced. ${ }^{40}$ The barratry statutes recently passed in four southern states, however, might prove effective barriers to association enforcement. ${ }^{47}$

42. See Note, 69 Harv. L. REv. 316,343 (1955).

43. Fogel v. Bolet, 194 Misc. 1019, 91 N.Y.S.2d 642 (Sup. Ct. 1949).

44. "Common barretry [sic] is the offence of frequently exciting and stirring up suits and quarrels . . . either at law or otherwise." 4 Blackstone, Commentaries "134; seo Vitaphone Corp. v. Hutchinson Amusement Co., 28 F. Supp. 526, 530 (D. Mass. 1939). Maintenance is "an offence that bears a near relation to ... [barratry]; being an officious intermeddling in a suit that no way belongs to one, by maintaining or assisting either party with money or otherwise, to prosecute or defend it . . ." 4 BLACKsTONE, ComMENTARIES *134; see LoGuidice v. Harris, 98 Ohio App. 230, 128 N.E.2d 842 (1954).

In general, barratry statutes add little to the Blackstonian definition, either defining barratry as the exciting of groundless judicial proceedings, e.g., N.D. REv. CODE \& 121716 (1943); N.Y. PEN. LAW $\$ 320$; restating the common law definition, as does KNN. GEN. STAT. $\$ 21-745$ (1949) ; or merely declaring common barratry to be a crime, with no further explanation, as does DeL. Code ANn. tit. 11, \& 371. (1953). Contra, statutes collected note 47 infra; see MD. Code ANN. art. 27, § 13 (1957); WaSH. Rev. Code ANN. § 9.12 .010 (1951) (detailed definitions). Those states having specific maintenance statutes have prohibited only one species-champerty. E.g., ME. REv. STAT. ANv. ch. 135, $\S 18$ (1954) ; N.Y. PEN. LAw $\S 3274-76$. "Champerty . . . being a bargain with a plaintiff or defendant ... to divide the ... matter sued for between them if they prevail at law; whereupon the champertor is to carry on the party's suit at his own expense." 4 BrAckStone, Commentaries * 135 .

45. See, e.g., Vitaphone v. Hutchinson Amusement Co., 28 F. Supp. 526, 530 (D. Mass. 1939) ; Boettcher v. Criscione, 180 Kan. 39, 299 P.2d 806, 811 (1956); Moffett v. Commerce Trust Co., 283 S.W.2d 591, 596 (Mo. 1955) ; State v. Batson, 220 N.C. 411, 17 S.E.2d 511 (1941).

Trade associations would probably at least be permitted to pay the expenses of a retailer suit. It has always been permissible "to maintain the suit of . . . a poor neighbor." 4 Blackstone, Conrasentaries *135; Rice v. Farrell, 129 Conn. 362, 28 A.2d 7 (1942) (dictum). And organizations formed to enforce legal rights of their members have been allowed to sue over barratry objections. Brannan v. Stark, 185 F.2d 871 (D.C. Cir. 1950), aff'd, 342 U.S. 451 (1952) (association of milk producers sought to enjoin enforcement of an order of the Secretary of Agriculture); Vitaphone Corp. v. Hutchinson Amusement $C_{0}$., supra (motion picture producers formed association to enforce their rights arising from the copyright law); Milk Dealers Bottle Exch. v. Schaffer, 224 Ill. App. 411 (1922) (a clearing-house for milk bottles sues to replevy bottles belonging to its members).

46. See Vose, N.A.A.C.P. Strategy in the Covenant Cases, 6 W. Res. L. REv. 101 (1955) ; Note, 50 Nw. U.L. REv. 289 (1955).

47. Miss. Code ANn. $\S \S 2049-01$ to -08 (1957) ; S.C. Code ANn. $\S \S 56-147$ to -147.6 (Supp. 1958); Tenn. Code ANn. §§ 39-3405 to -3410 (Supp. 1958); VA. Code ANN. $\$ \S 18-349.25$ to -349.30 (Supp. 1958). The Mississippi Code, for example, forbids any person or group to "promise, give, or offer, . . . receive or accept, . . . solicit, requuest or 
In fact, associations of retailers seldom bring fair trade suits. Their failure to do so is probably attributable to anticipation of success disproportionate to the expense involved. ${ }^{48}$ They may, therefore, view their most effective role as identifying violations and stimulating manufacturer enforcement. ${ }^{40}$ In addition, there might not be a sufficient consensus within most retail associations either on the desirability of observing maintained prices or on the dues necessary to support an enforcement program. Many such associations are composed both of those who favor and those who disapprove of resale price maintenance, of price cutters and fair traders. ${ }^{50}$ Nor have groups of fair-trading retailers formed specifically for collective enforcement of maintained prices generally arisen. Expenditures in relation to potential success would remain a deterrent, while apportionment of litigation expenses among a diverse group, possible reluctance to make a firm fair trade commitment and, perhaps, failure of initiative, could make organization difficult.

\section{The Manufacturer}

The fair-trading manufacturer does not face many of the obstacles which deter enforcement by individual retailers and their associations, and most fair trade litigation has therefore been carried on by manufacturers. ${ }^{\text {.1 }}$ Manufacturers of fair-traded products ordinarily possess greater resources than most retailers or groups of retailers. In addition, the manufacturer need not meet the onerous burden of establishing that he was damaged. In most states, the fact that a retailer has cut the price of a manufacturer's product suffices to give the manufacturer standing to bring an action against the price cutter. ${ }^{.2}$

donate, any money ... or any other assistance as an inducement . . to commence or prosecute . . . any proceeding." MIIss. CODE ANN. $\S 2049-01$ (1957). There is little doubt that these statutes were aimed at the National Association for the Advancement of Colored People. See 1 RAce Rex. L. Rep. 956 (1956) (proposal of the Attorney General of Georgia, recommending the passage of an act restricting the activities of organizations seeking to encourage litigation); Va. Acts of 1956, ch. 34 (authorizing a committee to investigate the activities of associations seeking to encourage litigation relating to racial activities), repealed, Va. Acts of 1958, ch. 373. A federal court has found the Virginiz statute violative of the equal protection and due process clauses of the fourteenth amendment, although the Supreme Court reversed it on procedural grounds. NAACP v. Patty, 159 F. Supp. 503, 533 (E.D. Va. 1958), rev'd on other grounds sub nom. Harrison v. NA.ACP, 360 U.S. 167 (1959).

A related Georgia statute, GA. Code ANN. § 26-4703 (Supp. 1958), which defines barratry as "frequently [to] engage in exciting and stirring suits ... [or to] propose ... to another person that they present and urge a suit," would probably be no hindrance to fair trade actions by retailer associations.

48. See notes 106-43 infra and accompanying text.

49. FTC REPoRt 243-49, 375.

50. E.g., Letter From the National Retail Merchants Ass'n to the Yale Lave Journal, May 14, 1959, on file in Yale Law Library.

51. GRETHER 344-45; see note 26 supra (about $90 \%$ of suits are by manufacturers).

52. See, e.g., Schwegmann Bros. Giant Super Mfarkets v. Eli Lilly \& Co., 205 F.2d 788 (5th Cir. 1953); Eastman Kodak Co. v. E MI F Elec. Supply Co., 36 F. Supp. 111 
While some manufacturers have testified for the federal bill, have publicly stated their support for fair trade, ${ }^{53}$ and have spent large sums on enforcement, this does not necessarily mean that they favor rigid price maintenance. The manufacturer has little to lose-and much to gain in retailer good willby open support of unenforced fair trade. ${ }^{54}$

There is considerable evidence of manufacturer disenchantment with fair trade. Many have abandoned it entirely by failing to set a minimum resale price. ${ }^{55}$ Others have openly tolerated or abetted cut prices, ${ }^{56}$ or have produced different brands or unbranded products which have been disposed of through non-fair-trade channels in competition with their fair-traded primary brands. ${ }^{\text {b7 }}$ There are even instances where manufacturers have urged retailers to sell under the fair-trade price. 58

Moreover, the manufacturer is less well placed to uncover fair-trade violations and obtain evidence of price cutting for litigation purposes than are retailers, and the costs of investigation alone for the manufacturer with a farflung distributive system may be prohibitive. ${ }^{50}$ To avoid the charge of discriminatory enforcement, he may be required to keep up a sustained attack on a large number of price cutters. ${ }^{60}$ Even the manufacturer who can afford the requisite investigation and litigation may consider such expenditures imprudent in light of the limited possibility of effectively eliminating price cutting. ${ }^{61}$ Nonenforcement by manufacturers may also reflect reluctance to risk damage to good will, since fair trade actions will subject the manufacturer to the inevitable defense of discriminatory enforcement, and litigation to enforce higher prices may cause unfavorable sentiment among non-fair-trading retailers and savings-minded consumers.

(D. Mass. 1940) ; Downs v. Benatar's Cut Rate Drug Stores, 75 Cal. App. 2d 61, 170 P.2d 88 (1946); Bristol-Myers Co. v. Picker, 302 N.Y. 61, 96 N.E.2d 177 (1950); Eli Lilly \& Co. v. Saunders, 216 N.C. 163, 4 S.E.2d 528 (1939); Borden Co. v. Schreder, 182 Ore. 34, 185 P.2d 581 (1947) ; Olin Mathieson Chem. Corp. v. L. \& H. Stores, Inc., 392 Pa. 225, 139 A.2d 897 (1958); Johnson \& Johnson v. Narragansett Wiping Supply Co., 1958 Trade Cas. 74711 (R.I. Super. Ct.).

53. See, e.g., 1959 Hearings 701-05.

54. See notes 106-43 infra and accompanying text.

55. See note 9 supra.

56. See, e.g., 1958 Hearings 608.

57. Miller, Unfair Competition 257 (1941) [hereinafter cited as Miller] ; Stocking \& Watkins 328; Corey, Fair Trade Pricing: A Reappraisal, Harv. Bus. Rev. Sept.Oct. 1952, p. 47; 1958 Hearings 219.

58. Seligman \& Love, Price Cutting and Price Maintenance 152 (1937) [hereinafter cited as Seligman \& Love].

59. See notes 31-32 supra and accompanying text; 1958 Hearings $276,279,609$. In Revlon, Inc. v. Wagonfeld, Trade Reg. ReP. (1959 Trade Cas.) đ 69353 (N.Y. Sup. Ct. April 21, 1959), the combined average cost of investigation and suit against each of eight retailers was over $\$ 1000$. State fair trade committees have advised smaller manufacturers that the expenses of fair trade might be prohibitive. FTC REPORT 39.

60. See notes 113-16 infra and accompanying text.

61. See notes 106-43 infra and accompanying text. 
The expense of fair trade enforcement and the possibility of injury to good will could be deemphasized if rigidly enforced fair trade gave the producer economic advantage. It might be thought that a manufacturer is able to set a higher price to dealers and take a higher margin of profits if he is permitted to fix the price to the ultimate consumer. But the manufacturer's price to dealers will be no higher merely because he controls the resale price. Whether or not the product is fair traded, its ultimate price to the consumer is determined by consumer demand and is composed of the manufacturer's price to the retailer plus the retailer's markup. In order to maximize his revenue, the manufacturer will seek to keep his price to the retailer as high as possible; conversely, to keep the retailer's markup as low as possible. But the retailer's profit margin cannot be pushed below a given minimum; otherwise he will be forced to discontinue the product. Since the retailer's markup has a floor, the manufacturer's share has a concomitant ceiling, which cannot be raised by resale price maintenance. The manufacturer's retailer price cannot be raised through fair trade without raising consumer price, and thus lowering demand.

Indeed, resale price maintenance may adversely affect the manufacturer's revenues by raising retailer markup. Since Robinson-Patman ${ }^{02}$ prohibitions of price discrimination prevent variation in the prices charged to dealers, the margin between the dealer price and the retail price, when both are set by the manufacturer, must be the same for all retailers, irrespective of their costs. If the manufacturer leaves enough margin so that the higher cost retailers (for whose benefit the manufacturer presumably adopted resale price maintenance) may profit, he will prevent the lower cost, larger scale retailers from passing on to the consumer the difference between their minimum working markup and the markup forced upon them by the producer's fair-trade policy. To the extent that higher prices reduce demand, the higher average retailer markup would result in lower overall demand for the product. facturer lowered his dealer price to offset the higher retailer markup and maintain demand, his profit margin would be lower.

Despite this disadvantage to the manufacturer, it has been nevertheless maintained that the manufacturer derives benefits from fair trade which expand consumer demand for his product more than enough to countervail the higher average retail markup. First, it is contended that resale price maintenance improves the effectiveness of advertising and allows the manufacturer to prevent dissipation, resulting from price cutting at the retail level, of his investment in good will. Second, fair trade is said to enable the manufacturer, by judicious use of higher retailer margins which can be guaranteed by fair trade, to ensure a better balanced and more effective distribution system.

The argument that fair trade protects the manufacturer's good will was endorsed without explanation in the 1936 Supreme Court case of Old Dcar-

62. Robinson-Patman Act, 49 Stat. 1526 (1936), 15 U.S.C. \& 13 (1958).

63. Section $2(a)$ of the act prohibits price discrimination "between different purchasers of commodities of like grade and quality."

64. See note 97 infra. 
born Distrib. Co. v. Seagram-Distillers Corp., ${ }^{05}$ and has since been followed by state and federal courts. ${ }^{06}$ This rationale forms the basis of the judicial presumption that price cutting constitutes "damage" to the manufacturer for the purpose of conferring standing to bring a fair-trade enforcement suit. ${ }^{07}$ It has further been developed by fair-trade proponents, ${ }^{08}$ who argue that unauthorized price cutting undermines a manufacturer's "standard price" and "quality" advertising.

"Standard price" advertising is most important in the case of products the demand for which is linked to high price. ${ }^{69}$ But such products are rarely fair traded, and resale price maintenance is not essential to the preservation of their appealing prices. Few products of this type are mass distributed since their supply is limited or intentionally held down. Further, most manufacturers of such goods will carefully select dealers who, aware that price cutting may diminish demand, will' not be likely to engage in price competition. Moreover, the manufacturer may keep his price to dealers at stuficiently high levels to ensure that the products will not be sold too cheaply.70

In the case of products which are normally fair traded, retail sales below the "standard price" advertised by the manufacturer should not destroy the effect of this advertising and may, in fact, stimulate additional consumer demand. Promotion which mentions price is usually aimed at convincing prospective purchasers that the cost is within their budgets, ${ }^{71}$ whether it is actually geared to the product's low price, or to a slightly higher price than other

65. 299 U.S. 183, 193 (1936). The Court further argued that good will is property which should be protected against injury. Id. at 194-95. Finally, relying upon a "grcat body of fact and opinion" and "legislative determination" that price cutting injures the "good will and business of the producer and distributor of identified goods . . . [and is] injurious to the general public as well," the Court upheld the validity of the Illinois Fair Trade Act. Id. at 195-96.

66. See, e.g., Remington Arms Co. v. Gatling, 128 F. Supp. 226 (W.D. Pa. 1955); Calvert Distillers Corp. v. Rosen, 115 F. Supp. 146 (N.D. Ill. 1953); Eli Lilly \& Co. v. Schwegmann Bros. Giant Super Markets, 109 F. Supp. 269 (E.D. La.), aff'd, 205 F.2d 788 (5th Cir. 1953) ; Olin Mathieson Chem. Corp. v. L. \& H. Stores, 392 Pa. 225, 139 A.2d 897 (1958).

6\%. See cases collected note 52 supra and accompanying text.

68. E.g., Weiger, The FaIr Trade Acts 15 (1938) [hereinafter cited as Weigel]; see Stocking \& Watkins 322-23; Grether 85; Seligman \& Love 185-86; Note, 65 Yale L.J. 235 n.6 (1956) ; Note, 61 Yale L.J. 381 n.2 (1952).

69. These are products usually purchased for purposes of conspicuous consumption. The demand for such products decreases as does the price. Seligasan \& Love 185-86; Stocking \& Watkins 331; Taussig, Price Maintentance, 6 Am. Econ. Rev. 170, 172-73 (Supp. 1916). But see Stigler, The Theory of Price 43-44 (1952) [hereinater cited as STIGLER] (no instances of more of a commodity being purchased at a higher price).

Sales of these products depend on their exclusive nature. SELIGMSAN \& LovE 185-86; Stocking \& Watkins 326, 331; Waite \& Cassidy, The Consuner and the Econonic Order 207 (1939); Norris, Theory of Consumer Demand 221 (1952); Kelley, ConSUMER DEMAND 228 (1953).

70. Cf. Note, 69 Harv. L. Rev. $316,324 \&$ n.61 (1955).

71. GRETHER 285. 
brands. If customers find that the product is offered for sale at prices below those generally advertised, they are likely to be more readily enticed into a purchase since the cut price will appear even more reasonable. The alternate hypothesis-that consumers will be repelled by a suspicion that the manufacturer is making exorbitant profits at the advertised price 72 -has never been empirically verified and, on its face, seems less tenable. A comparable disparity between the selling price of the fair-trading retailer and discount seller will also obtain for competing goods whether fair traded or not. And, seeing that the advertised product's cut-rate price remains proportionally constant to those of competing products, ${ }^{73}$ the buyer will be unlikely to view the standard price as inordinate. The fact that non-fair-traded products can be and are commonly advertised as selling at the manufacturer's suggested price it is further proof that fair-trade price rigidity at the retail level is unnecessary to effective "standard price" advertising.

The argument that price maintenance would enable manufacturers to prevent price cutting from undermining advertising which emphasizes product quality is more forceful. The great disparity in price resulting from competition at the retail level, it is contended, will cause consumers to doubt the quality of the product. ${ }^{75}$ Use of a product as a "leader"-selling it at a particularly low price in order to attract consumers and promote sales of all merchandise-is viewed as particularly injurious to the manufacturer's quality reputation. ${ }^{78}$ But this argument overlooks some vital facts of price cutting and "leader" selling. The retailer's purpose is defeated if consumers associate cutting of the leader's price with a dimunition in its quality. ${ }^{77}$ The retailer will therefore emphasize the quality of the leader as a necessary part of the selling campaign, thus perhaps increasing, rather than decreasing, the product's

72. See The Brandeis Gutoe to tre Mfodern World 216 (Lief ed. 1941) [hereinaiter cited as BRANDEIs].

73. If the normal retail price is higher than that of competing products, price to dealers usually will be proportionately higher, and therefore the advertised product's discounted price should bear the same relation to the discounted prices of other products as will their undiscounted prices. A similar result will obtain if the advertised product's normal price is lower than that of competing brands.

74. See, e.g., Esquire, March 1959, p. 19 (slacks ad) ; Life, April 6, 1959, p. 142 (carpeting).

75. See Weiger 15; Brandeis 216; Seligaran \& Love 185-86; Fulda, Resale Price Maintenance, 21. U. ChI. L. Rev. 175, 184-86 (1954); Note, 65 YALE L.J. 235 n.6 (1956); Note, 61 Yare L.J. 381 \& n.2 (1952). See also Stigler 44; Stocking \& Watrins 331; Haring, Retail Price Cutming 8, 144 (1935) [hereinafter cited as Haring]; Note, 69 HARv. L. REV. 316, 327 (1956).

76. See Yasiey 94; Zorn \& Feldaran, Business Under the New Pryce Laws 267 (1937) [hereinafter cited as ZoRN \& Feldacan]; Haring 7-S; Bowman, The Prerequisites and Effects of Resale Price Maintentance, 22 U. CEI. L. REv. 825, 836 (1955).

77. Seligaran \& Love 145; Grether 267; see Yadrex 64. Ordinarily, products used as leaders are widely known brands which the consumer associates with quality. See Statement of Stanley Weigel, 1959 Hearings 349-50; 1958 Hcarings 368; Y AssE 63-64, 98 \& n.2; Grether 203, 267; Note, 61 Yale L.J. 381 \& n.2. 
good will. ${ }^{78}$ Additionally, use of a manufacturer's product as a leader should, by lowering its price, stimulate demand (a stimulus which is treated by the retailer as an advertising expense).$^{79}$ Competing retailers' sales of the product employed as a leader are likely to drop off-it is these retailers who are injured by "leader" selling-but the lower average retail price should increase overall demand for the manufacturer's product.

Use of the manufacturer's product for "bait" or substitution selling, it is true, may adversely affect the manufacturer's quality advertising. Substitution selling occurs when a dealer advertises a well known product for sale at $\mathfrak{a}$ lower than usual price in order to create the false impression that he sells other articles of standard or known value on similarly favorable terms. The substitution seller, having thus attracted customers, will attempt to induce buyers to purchase substitutes on which the dealer makes a higher profit. ${ }^{80}$ Since the dealer's efforts to substitute the more profitable product for the "bait" will normally involve deprecation of the latter, the manufacturer's good will could be seriously injured. But such practices face illegality under both the Federal Trade Commission Act ${ }^{81}$ and state statutes prohibiting false and misleading advertising. ${ }^{82}$ It is doubtful that additional illegality under the fairtrade laws would substantially assist in eliminating substitution selling. In

78. Seligman \& Love 145; Grether 267. Even if the price cutter did not point out the stability of the quality, the average consumer realizes that a reduced price on several widely advertised products is not due to a sudden change in quality but rather to the retailer's desire to attract business. See Schactman, Resale Price Maintenance and the Fair Trade Lazes, 11 U. PrTT. L. REv. 562, 577 (1950). The use of leaders is usually accompanied by advertising on the retail level, in order to inform the consumer of the bargain. Yantey 39; Watte \& Cassidy, The Consumer and the Economic Orden 305 (1939); Kelley, Consumer Economics 239-40 (1953). 15.

79. YameY 98; ZoRn \& FELDMAan 256; Statement of Q. Forrest Walker, in HIArung

80. GRETher 267-69; ZoRn \& FeLdMAN 267; YAMEY 99; HARING 27, 191; Bowman, supra note 76 , at 836 . In fact, price maintenance may encourage substitution. A price cutter, although unable to advertise a fair-traded product at a cut price, can compare the prices of that product and a private brand of like quality once the customer is in the store. Ibid.

81. Section 5, 38 Stat. 719 (1914), 15 U.S.C. \& 45 (1958) (proscribing "unfair methods of competition"). For FTC rulings that "bait" advertising constitute violations of $\S 5$, see Forrest A. Jones, 52 F.T.C. 1192 (1956); 16 C.F.R. $§ 25.20$ (1959) (trade practice conference rules for combination storm window and door industry).

82. Some states specifically prohibit "bait" advertising. E.g., N.Y. GEN. Bus. LAW § 361 ; see Note, 56 Colum. L. Rev. 1019, 1063 \& n.275 (1956). Forty-four states and the District of Columbia have enacted the "Printers Ink Model Statute." Id. at 1058. This statute makes violations a misderneanor and requires proof of three clements: (1) an intent to sell, dispose of, or increase the consumption of goods or services; (2) the advertising of such intent; and (3) the existence in such advertising of statements or representations of fact which are untrue, deceptive or misleading. Id. at 1059 ; e.g., N.Y. PEN. LAw \& 421. This statute has been used against "bait" advertising, People v. Glubo, 5 N.Y.2d 461, 158 N.E.2d 699, 186 N.Y.S.2d 25 (1959), but is relatively untested in this area. 
addition, substitution selling, because of its illegality and ineffectiveness, is rare and is used only by less scrupulous dealers. ${ }^{83}$

It has also been argued that fair trade can aid the manufacturer in the development of a more advantageous distribution system. By assuring higher markups through price maintenance, the manufacturer may be able to prevent the competitive elimination of fair-trade outlets. ${ }^{84}$ Even if such retailers do not make large volume sales, it is argued, they promote the manufacturer's products personally to individual buyers ${ }^{85}$ and display the products more widely. ${ }^{86}$ The greater accessibility of the products is said to encourage impulse purchases by customers frequenting proximately located stores ${ }^{67}$ and provide relatively inexpensive advertising. Furthermore, competitive elimination of fair-trade retailers, it is contended, would leave a relatively small number of large retailers and place the manufacturer in a less advantageous bargaining position. The remaining retailers, the argument runs, may force price concessions from the manufacturer-particularly the smaller producer. ${ }^{88}$ Once their market power is sufficient, they may also take a higher markup to maximize their profits and thereby decrease sales below the point of optimum revenue for the manufacturer. ${ }^{89} \mathrm{Or}$, having exhausted the competitive advantages of using the product as a leader, they may drop it.90

These arguments are far from persuasive. While the typical manufacturer will desire a maximum number and variety of retail outlets, the number which he can profitably service and supply may be limited. He will therefore wish to retain only those outlets for which the costs of service and supply do not outweigh the increased revenues from these outlets plus the advantages which he may derive from wider display and promotion. ${ }^{01}$ It is unlikely that the absence of price maintenance would force out of business large numbers of key retailers; the retailers most vulnerable to price competition are those from which the manufacturer will ordinarily draw little revenue. 153.

83. 1958 Hearings 603-04, 614, 617, 632; YaAreY 99-100. Bull sec Seugasas \& Lofe

84. Grether 268, 269; Y YMrey 49, 91, 105; Bowman, supra note 76, at 837; Note, 64 HARv. L. Rev. 1327 (1951). The primary purpose of fair trade was to prevent small retailers from being driven out of business by price cutting. View of Department of Commerce in Hearings on H.R. 5767 Before the Scnate Conmiltee on Interstate and Forcign Comnserce, 82d Cong., 2d Sess. 9 (1952) ; Statement of Dr. John Blair, Assistant Chiei Economist of the Federal Trade Commission, id. at 33.

85. See YaArey 4-5; FTC Report 134-35; Wescel 15; Bowman, supro note 76, at 846 n.65; Hawkins, Further Theoretical Considerations Regarding Fair Trade Lozus, 4 J. MLARKETING 126, 128 (1939).

86. See Grether 269, 270-71; Bowman, supra note 76, at 827; Note, 64 HAsv. L. REv. 316, 327 (1955).

87. See Yaxrey 49-52; Corey, Fair Trade Pricing: A Reappraisal, Harv. Bus. Rer. Sept-Oct. 1952, pp. 47, 51,

88. See Yamey 9, 18-19; Haring 42-45, 49-50, 125; Grether 269; Stocking \& Watkixs 323; Note, 61 Yale L.J. 381, 391 (1952).

89. See YANAEY 91; Bowman, supra note 76, at 838.

90. GRETHER 269; ZoRN \& FeLdMAN 267; Branders 217.

91. See Haring 164; Seligaran \& Love 201. 
Increased bargaining power of retailers through the elimination of small competitors should pose little threat to manufacturers. ${ }^{02}$ While the economies of scale in retailing seemingly dictate larger outlets and chains, it is doubtful that the optimum size of the retail firm is so large that, under competitive conditions, only a number which would constitute a highly concentrated market would survive. ${ }^{93}$ Since viable size would probably be attainable by new entrants, attempts to raise markups above competitive levels or to drop a popular product would signal the establishment of new outlets.

It is further argued that the retailer, in exchange for the higher markup furnished by fair trade, will be more active in persuading consumers to buy the price-maintained product, will make greater advertising outlays, display the product more prominently, and provide additional services in promoting sales of the product. At the same time, he will attempt to discourage sales of competing, non-fair-traded products, on which he is not assured as advantageous a markup. ${ }^{94}$ The principal difficulty with this argument, assuming its validity, is that competing manufacturers may pursue the same policy. If so, the retailer will have no reason to promote one product rather than another; his markup on all sales will be similarly guaranteed. ${ }^{.55}$ When that occurs, the retail price for all brands is increased. ${ }^{96}$ The result may be a decrease in demand for the item, diminishing industry revenue. ${ }^{.7}$

92. It is unlikely that the number of retailers will be so reduced in most areas as to constitute an effective oligopsony. YAMEX 91; GRETHER 279. And any agreement which would achieve this effect would probably violate Sherman Act $\$ 1,26$ Stat. 209 (1890), as amended, 15 U.S.C. $\$ 1$ (1958).

Further, the enhanced market power of large retailers might pose no greater threat to manufacturers than the power currently possessed by some of the associations of fairtrading retailers. See FTC REPORT 166-218; MuNd 440; 1958 Hearings 633.

93. See Bain, Barriers to New Conpetition 11-15 (1956).

94. See notes $86-87$ supra and accompanying text.

95. See YAMEY 8-10; Hawkins, Further Theorctical Considerations Regarding Fair Trade Laws, 4 J. Marketing 126, 128 (1939); Bowman, Resale Price MaintenanceA Monopoly Problem, 25 U. CHI. J. Bus. 141, 150 (1952).

96. Most commentators are in agreement that fair trade has resulted in an increase in prices above those prevailing in a state of competition. See, c.g., WAITE \& CAssidy, The Consumer and the Economic Order 267 (1939); Stocking \& Watkins 324, 329. 30 \& n.34; FTC Report XLV-LI, 131-35; YAMEY 3-4, 109, 130; SELIGMaN \& Lovi 230; Schactman, silpra note 78, at 584; Herman, $A$ Note on Fair Trade, 65 Y ALE L.J. 23,25 (1955) ; Comment, 61 YALE L.J. 381, 390 (1952); Letter From Eugene V. Rostow, Dean of Yale Law School, 1958 Hearings 661. But see Adams, Resale Price Maintcnance: Fact and Fancy, 64 YALE L.J. 967 (1955), and Fair Trade and the Art of Prestidigitation, 65 Y $\mathrm{ALE}$ L.J. 196, 199, 202-03 (1955). And such consumer welfare organizations as have submitted statements or testified before the 1958 hearings have all been in agrecment as to the increase in price caused by fair trade. See Statements of Consumer's Federation of St. Louis, 1958 Hearings 199-207; Consumers Conference of Greater Cincinnati, id. at 239-43; Consumers Information Bureau, id. at 676-78. See also Consumers Reports, May 1958, reproduced in $i d$. at 212-18, and statements submitted by farmers, id. at 320-21 (American Farm Bureau), 643-44 (Kansas Farm Bureau).

But the proponents of fair trade legislation have sought to prove that fair trade has not caused a price increase. They argue that most surveys have not been truly repre- 
Furthermore, direct adjustments in price (advertising or service allowance) would provide a more effective incentive to compensable retailer promotion..$^{88}$ Unlike the higher retailer markup resulting from fair trade, which all retailers would receive regardless of performance, such allowances can be made contingent upon effective promotional efforts. ${ }^{93}$ Provided such allowances are available on proportionally equal terms to all outlets, they would not constitute Robinson-Patman price discrimination. ${ }^{100}$ Such allowances, of course, could be paid for by the manufacturer through an increase in price to his dealers. If the retailer passes this increase on to the consumer, the effect upon product demand should be no more serious than a higher fair-trade price.

If the price-maintenance markup provided a sufficiently strong inducement for a substantial number of dealers to agree to sell the manufacturer's fairtraded products exclusively, the manufacturer would gain considerable advantage over his competitors. ${ }^{101}$ But it is highly dubious that the offer of a fairtrade markup would be sufficient consideration for an exclusive dealership. Further, the desired result-foreclosure of a substantial number of outletswould be subject to attack under section 3 of the Clayton Act. ${ }^{102}$

None of the foregoing advantages clained for fair trade, even if they outweigh the adverse effects of higher average retailer markups, would aid the manufacturer unless he could afford to ignore dealers who refuse to adhere to fair-trade prices. If he, through fair trade, fully protects price-maintenance dealers in any market area, he must forego distribution of his product through the price cutters in that area. Such a position could profitably be taken only by the unusual manufacturer who can sufficiently differentiate his products to create an inelastic demand unaffected by higher price and thus force the price cutter to sell the product at the fair-trade price or lose business. ${ }^{103}$ In the case of the typical product, however, a price cutter would counter a manufacturer's insistance on price maintenance with the promotion of competing, non-fair-traded substitutes. ${ }^{10 \leq}$ MIoreover, a manufacturer cannot enforce price

sentative, and that a Nielson survey, sponsored by the Bureau of Education on Fair Trade, comparing prices on 15 brands in fair-trade areas and non-fair-trade areas proves the consumer, in general, pays about the same for each brand in both areas. Statement of Maurice Mermey, Director, Bureau of Education on Fair Trade, 1959 Hcarings 62. But if the Nielson survey is accurate, the manufacturer has no need for fair trade.

97. YaMeY 11; Harrig 189, 191. If the product as a group has a classical demand curve, as is most probable, the increased price will cause a decreased demand. Sricuen 43-44; Saxruerson, Econosics 441 (4th ed. 1958).

98. HaRING 42; YaMrEY 53-55. See generally HARING 42-65 on advertising allowances.

99. See sources cited note 98 supra.

100. See ATr'y Gen. ReP. 189-90.

101. See YAureY 20; Bowman, supra note 76, at 845-48.

102. 38 Stat. 731 (1914), 15 U.S.C. \& 14 (1958).

103. See HARING 8; FTC REPORT 7-8; 1959 Hearings 502; Bowman, supra note 76, at 836 .

104. See Gkether 267-68, 272-73; Harixg 7; Seliguan \& Love 178-79; Yauey 6. 
maintenance against some dealers and at the same time distribute products to and abstain from prosecution of other large volume price cutters. Any attempt at such discriminatory enforcement would be defeated. ${ }^{105}$

In view of the increasing share of the retail market possessed by the nonfair-trade dealers, few manufacturers would be willing to give up sales to these outlets. In addition, display and promotion by high-overhead price-maintaining retailers, with limited advertising budgets, would seldom be of greater import than the promotion resulting from price competition. Furthermore, the mass media typically employed by price cutters may reach more buyers, while lower price tags may be more persuasive than the most diligent personal promotion. In sum, the impossibility of reconciling a vigorous fair-trade enforcement program with the preponderant role of "price cutters" in promoting and selling their goods, combined with the speculative nature of fair trade's benefits when compared with its escalator effect on average retailer markup, would indicate that the ordinary manufacturer would be unenthusiastic or, at best, neutral about fair-trade enforcement.

\section{Fair Trade Remedies}

Whatever the interests of retailers and manufacturers in fair trade, their ability to bring successful actions against price cutters necessarily depends upon the remedies available. Most state statutes do not explicitly provide remedies; they merely make price-maintenance violations actionable, and thus leave the courts and the parties free to determine appropriate relief. ${ }^{100}$ The federal bill, following the minority states, ${ }^{107}$ would effectuate enforcement specifically through injunction and an award of "damages sustained." 108 In addition, victorious plaintiffs would recover reasonable counsel fees from violators. ${ }^{10 g}$

An injunction against future price cutting is the remedy most often obtained in suits under state fair trade laws. ${ }^{110}$ But a considerable obstacle to successful injunctive actions by retailers is the ubiquitous equitable defense of "unclean hands," which, in this context, means that the plaintiff has also sold

105. See notes 113-16 infra and accompanying text.

106. E.g., Cai. Bus. \& Prof. Code § 16904; N.Y. Gen. Bus. Law \$ 369-a.

107. E.g., Me. Rev. Stat. ANv. ch. 183, \& 4 (1954) (injunction plus three times amount of actual damages); N.H. Rev. Stat. ANn. $\$ 357: 4$ (1955) (same).

108. H.R. 1253, 86th Cong., 1st Sess., § 2, p. 7, lines 6-11 (1959).

109. H.R. 1253, supra note 108 , at 7 , lines 12-13.

110. Although most fair trade acts contain no specific provision for injunctive relief, see note 106 supra and accompanying text, such relief has been frequently awarded, see, e.g., Ampex Corp. v. Goody Audio Center, Inc., 5 Misc. 2d 1072, 163 N.Y.S.2d 191 (Sup. Ct. 1957). Other statutes expressly provide for injunctive relief. See note 107 supra.

It is thought by some that an injunction is the only practical method of enforcing resale price maintenance. See Calvert Distillers Corp. v. Nussbaum Liquor Store, Inc., 166 Misc. 342, 347, 2 N.Y.S.2d 320, 325 (Sup. Ct. 1938) ; Note, 36 Cons. L.Q. 781, 790 (1951). 
the product at less than the maintained price. III If plaintiff could prove that his price cutting, indulged in only to meet competition, postdated that of defendant, and that he promptly brought suit, it might be argued that a presumption that plaintiff's price cutting was self-defensive should arise which would overcome his unclean hands. But such a theory has not received judicial recognition. Nor have courts generally been willing to condition decrees upon plaintiff's agreement to abstain from future price cutting or upon plaintiff's consent to submit to a similar decree. ${ }^{112}$

Injunctive suits by manufacturers have likewise been prevented by a defense which carries the label of "unclean hands." A manufacturer's "unclean hands" refers to discrimination in his enforcement-the selection of defendant from a number of equally culpable, but unsued, price cutters. ${ }^{113}$ This defense may be based on the rationale that the manufacturer, by his failure to sue, has abandoned price maintenance or is estopped from any enforcement. ${ }^{114}$ Alternatively, or in addition, the defendant may claim that singling him out for prosecution would unjustly disadvantage him in relation to competitors. ${ }^{115}$ Since a manufacturer cannot simultaneously prosecute every price cutter, the defendant who alleges discriminatory enforcement must affirmatively demonstrate the manufacturer's failure to follow a consistently diligent enforcement policy. ${ }^{116}$ But, probably because manufacturers are hesitant to prosecute large-

111. See, e.g., Boesch v. Johnson Wholesale Perfume Co., 9 Conn. Supp. 110 (Super. Ct. 1941); Bathasweet Corp. v. Weissbard, 128 N.J. Eq. 135, 15 A.2d 337 (Ch. 1940); Fogel v. Bolet, 194 Misc. 1019, 91 N.Y.S.2d 642 (Sup. Ct. 1949).

112. Such a consent decree was the solution adopted in Gurock v. Brandie-Wine Stores, Inc., 101 N.Y.L.J. 38 (Sup. Ct. 1939).

113. See Lionel Corp. v. Klein, 114 A.2d 652 (Ch. Del. 1955); Hutzler Bros. v. Remington Putman Book Co., 186 Mid. 210, 46 A.2d 101 (1946). But sec Calvert Distillers Corp. v. Harry Fox, Inc., 87 N.Y.S.2d 470 (Sup. Ct. 1941); National Distillers Prods. Corp. v. Columbus Circle Liquor Stores, Inc., 166 ACisc. 719, 2 N.Y.S.2d 319 (Sup. Ct. 1938). And, an injunction has been made conditional upon continued vigorous eniorcement by the manufacturer. General Elec. Co. v. R. H. Afacy \& Co., 199 Misc. 87, 103 N.Y.S.2d 440 (Sup. Ct. 1951).

Most decisions denying the defense of "unclean hands" have been based upon a finding of a sincere effort by the manufacturer to enforce his prices, in spite of a lack of success. See, e.g., Eastman Kodak Co. v. Lee-Wilson, Inc, 13S F. Supp. 591 (D. IIass. 1955) ; Revere Copper \& Brass, Inc. v. Grayson-Robinson Stores, Inc, 120 F. Supp. 258 (S.D.N.Y. 1954) ; Lionel Corp. v. Klein, supra; Eastman Kodak Co. v. Schwartz, 133 N.Y.S.2d 908 (Sup. Ct. 1954); Hutzler Bros. v. Remington Putman Book Co., supra.

114. General Elec. Co. v. American Buyers Co-op., Inc, 1956 Trade Cas. 71514 (Ky. Cir. Ct.) ; Magazine Repeating Razor Co. v. Weissbard, 125 N.J. Eq. 593, 7 A.2d 411 (Ch. 1939); Olin Mathieson Chem. Corp. v. A. Rosenblum, Inc., 1958 Trade Cas. 74510 (N.Y. Sup. Ct.).

115. See Mriles Labs., Inc. v. Ann \& Hope Factory Outlet, Inc., 1958 Trade Cas. 74816 (R.I. Super. Ct.) (defense allowed). Contra, Calvert Distillers Corp. v. Stockman, 26 F. Supp. 73 (E.D.N.Y. 1939). Cases where the plaintiff is a retailer have also involved the "competition" defense. See Ray Kline, Inc. v. Davega-City Radio, Inc., $16 S$ Misc. 185, 4 N.Y.S.2d 541 (Sup. Ct. 1938) ; Schimpf v. R. H. Mracy \& Co., 166 Misc. 654, 2 N.Y.S.2d 152 (Sup. Ct. 1938).

116. See cases cited note 113 supra. 
volume price cutters, who may be good customers, the defense has not been difficult to establish.

Another limitation of injunctive relief is that it is inoperative during the often lengthy interval between bill and decree. While plaintiffs have sought to overcome this defect by requesting preliminary injunctions or temporary restraining orders, the courts have been unwilling freely to grant these extraordinary remedies. ${ }^{117}$ Issuance of such interim relief requires a high standard of proof; irreparable injury to plaintiff which outweighs any possible interim damage to the defendant. ${ }^{118}$ Since normally only affidavits rather than evidence are received at the hearing, ${ }^{119}$ an apparently bona fide defense which eventually proves unsupportable can defeat issuance of temporary decrees or orders. ${ }^{120}$

The inconsequence of the fines awarded to the plaintiff if the defendant is held in contempt has also limited the effectiveness of injunctions. The amount is fixed by the courts, ${ }^{121}$ unless limited by statute, ${ }^{122}$ and, possibly because they lack conviction that price cutting should be deterred, they have usually set fines at low levels. ${ }^{123}$ Thus, the defendant has been able to continue his price cutting, submitting himself to periodic contempt assessments as part of the

117. See, e.g., General Elec. Co. v. American Wholesale Co., 235 F.2d 606 (7th Cir. 1956) ; Mogen David Wine Corp. v. Borenstein, 267 Wis. 503, 66 N.W.2d 157 (1954). In New York, however, the courts have been more lenient. See General Elec. Co. v. Masters, Inc., 122 N.Y.S.2d 14 (Sup. Ct. 1952), aff'd, 281 App. Div. 827, 118 N.Y.S.2d 927 (1953) (granting plaintiff's motion for a preliminary injunction against price cutting although a triable issue of fact existed).

118. See Comment, 40 Marg. L. Rev. 191 (1956). See also de Funiak, Modern EQuirY 16 (1950); Note, 4 S.C.L.Q. 540 (1952).

119. See 4 Restatement, Torts $\$ 936$, comment $e$ (1939); cases cited note 120 infra.

120. See, e.g., Boesch v. Johnson Wholesale Perfume Co., 9 Conn. Supp. 110 (Super. Ct. 1941) ; Anderson v. Sonbac Sales Corp., Trade Reg. Rep. (1959 Trade Cas.) \69287 (N.Y. Sup. Ct. Feb. 10, 1959).

121. E.g., Donner v. Calvert Distillers Corp., 196 Md. 475, 77 A.2d 305 (1950); sec United States v. United Mine Workers, 330 U.S. 258 (1947); United States v. Brotherhood of R.R. Trainmen, 95 F. Supp. 1019 (D.D.C. 1951).

122. In New York, for example, the maximum fine is set by statute at $\$ 250$ plus costs. N.Y. JudictaRY LAW $\S 773$.

123. See Sunbeam Corp. v. Quint, 139 F. Supp. 804 (D. Mass. 1956) (costs of conducting contempt proceeding $\$ 750$, fine of $\$ 500$ for "divers" violations-"I do not believe that ... [I am obligated] to award plaintiff's actually incurred expenses, but only what ... would appear somewhat conservatively reasonable."); General Elec. Co. v. Trubitz, 1956 Trade Cas. 71184 (N.Y. Sup Ct.) ( $\$ 100$ fine for two violations; motion for costs plus attorney's fee denied); Sherwin Williams Co. v. J. P. Paint Co., 1956 Trade Cas. 71183 (N.Y. Sup. Ct.) ( $\$ 50$ fine for one violation); Eastman Kodak Co. v. Bernstein, 1956 Trade Cas. 72311 (N.Y. Sup. Ct.) (fine of $\$ 400$ for 4 violations plus $\$ 150$ counsel fee) ; Revere Copper \& Brass, Inc. v. Harvard Stores, Inc., 1955 Trade Cas. 70158 (N.Y. Sup. Ct.) (fine of $\$ 50$ plus $\$ 50$ counsel fee). But sec Sunbeam Corp. v. J. Eis \& Sons Appliances, 1956 Trade Cas. 71693 (S.D.N.Y.) (defendant ordered to pay plaintiff's $\$ 600$ expenses including attorney's fees for bringing 6 violations to notice of court); E. I. du Pont de Nemours \& Co. v. Wallach, 4 Misc. 2d 796, 162 N.Y.S.2d 457 (1956) 
price of doing business. It is not unusual for an aggressive retailer to be held in contempt of fair-trade injunctions a dozen or more times.12t

Recently, an attempt has been made in Sunbcam Corp. $v$. Golden Rulc Appliance Co. ${ }^{125}$ to overcome the difficulties of proving the extent of contempt-caused losses through the assessment and award of a sum equal to the contemnor's profits on sales made in violation of the injunction. ${ }^{120}$ The Second Circuit stated that postinjunction profits should be awarded a manufacturer-plaintiff, but three separate opinions advanced three different theories. According to Judge Hincks, the defendant had misappropriated the manufacturer's good will and must therefor account for profits derived from property illegally dealt with. ${ }^{127}$ The theories of the two concurring opinions would appear equally applicable when a retailer is seeking the contempt award. Judge $I$. Hand reasoned that the price cutter received the goods subject to the lawful condition that they would not be sold below the fair-trade price, and that his profits could be assessed to the extent that he violated that condition. ${ }^{128}$ Judge Lumbard viewed the assessment of profits simply as an appropriate contempt fine for violation of a fair-trade injunction, in the absence of a statutory limitation of such fines. ${ }^{129}$

The Hincks and Hand Golden Rule opinions suggest that accountings can be ordered, as original relief, as well as assessments for contempts stemming

( $\$ 500$ fine for "several" violations); General Elec. Co. v. Afacher Watch Co., 1950-1951 Trade Cas. 64118 (N.Y. Sup. Ct. 1950) (fined $\$ 250$ for one violation).

These sums seem particularly low in view of the fact that each known violationusually brought to light by professional investigators-probably represents countless unknown violations.

In New York, where preliminary injunctions are not unusual, see note 117 sipro, they have been made permanent through consent decrees, which contain fairly high penalties in case of noncompliance, see, e.g., General Elec. Co. v. Nathan S. Goldfarb Estate, Inc., N.Y.L.J. Feb. 26, 1958, p. 6, col. 6 (Sup. Ct.) ( $\$ 500$ for two cut-rate sales plus $\$ 150$ counsel fees). These penalties seem functionally closer to the in ferrorem fine than to the normal civil contempt fine. See notes 135-37 infra and accompanying text. Absent the availability of temporary injunctive relief, however, see note 117 supra and accompanying text, consent decrees would be unusual, and this method of fair trade enforcement rare. Nonetheless, such a procedure is not unknown outside of New York. See Seagram Distillers Corp. v. Mills Cut Rate Liquor Míart, Inc, 1957 Trade Cas. 72824 (MId. Cir. Ct.).

124. E.g., Brief for Appellee, p. 6 (19 different occasions), Sunbeam Corp. v. Golden Rule Appliance Co., 252 F.2d 467 (2d Cir. 1958).

125. 252 F.2d 467 (2d Cir. 1958).

126. The notion of recovering the price cutter's profits apparently derives from patent and trademark cases, in which the courts have allowed the owner of the patent or mark to recover the profits of an infringer. See, c.g., Maternally Yours, Inc. v. Your Maternity Shop, Inc., 234 F.2d 538 (2d Cir. 1956); Blue Bell Co. v. Frontier Ref. Co., 213 F.2d 354 (10th Cir. 1954).

127. $252 \mathrm{~F} .2 \mathrm{~d}$ at $470-71$.

128. Id. at 471 .

129. Id. at 472 . Since the action was in a federal court, Judge Lumbard reasoned, the New York statutory limit on contempt fines, see note 122 supro, was inapplicable. 
from disobedience of an injunction, under those state statutes which do not specifically provide remedies. ${ }^{130}$ But in the only reported case in which an accounting was sought as a primary remedy, Sunbeam Corp. v. Civil Scrv. Employees' Co-op. Ass'n, ${ }^{131}$ the Third Circuit required that a manufacturerenforcer prove injury in the amount of the defendant's profits. ${ }^{132}$ Such a requirement, designed to prevent a windfall to the plaintiff, would normally render any recovery of profits impossible. But even if the proof-of-damage rule of Civil Service, which was decided seven years before Golden Rule, is inapplicable in contempt actions, or in suits by retailers, ${ }^{133}$ plaintiff might not be able to prove the amount of defendant's profits in violation of the injunction. The experienced price cutter, fearing contempt action (or bills for accounting), may not keep or may destroy inculpating records. ${ }^{134}$ In Goldcn Rule itself, spoliation of defendant's records was allowed to defeat the recovery entirely. ${ }^{135}$

Plaintiffs have also sought in terrorem fines. ${ }^{130}$ Such fines are imposed prospectively and determine in advance, similarly to liquidated damages provisions, the amount which contemnor must pay to plaintiff upon future violation. ${ }^{137}$ In addition, the defendant may sometimes be forced to accept an ex parte finding of subsequent violation..$^{138}$ The use of in terrorem fines in fair trade enforcement is of recent date, and, in view of the fair trade history of ordinary contempt fines, their future is at best uncertain.

Damages have also proved an unsatisfactory remedy for the enforcement of resale price maintenance. Although damages have been frequently requested, ${ }^{130}$ they have been awarded to manufacturers in only three reported cases-in one case compensatory plus exemplary damages; $\mathbf{1}^{100}$ in another, nominal plus

130. See note 106 supra and accompanying text.

131. 187 F.2d 768 (3d Cir. 1951), cert. denied, 342 U.S. 909 (1952).

132. The reasoning of the Third Circuit was that a manufacturer receives the same profit on each article whether the article was sold at or below the fair-trade price, and therefore he had no right to profits of the defendant. 187 F.2d at 773. This reasoning is directly contra to Judge Hincks' Golden Rule opinion for the court, although not to Judge Hand's concurring opinion.

133. See 187 F.2d at 773 ("if anyone has lost anything by virtue of price reduction $\ldots$ it is other retailers who might have sold the goods ... at the regular price and made a profit").

134. Cf. note 32 supra and accompanying text.

135. 252 F.2d at $472,473$.

136. 'See Sunbeam Corp. v. Golden Rule Appliance Co., 252 F.2d 467, 471 (2d Cir. 1958); General Elec. Co. v. Waldman, 159 F. Supp. 576 (W.D. Pa. 1958); Gencral Elec. Co. v. Dinsen \& Co., 1954 Trade Cas. 69272 (N.Y. Sup. Ct.).

137. See United States v. United Mine Workers, 330 U.S. 258 (1947).

138. The amount of the fine is determined with an eye toward deterrence of the defendant; the most important factor is his financial situation. See id. at 303-07.

139. Note, 69 Harv. L. Rev. 316, 321 n.4 (1955).

140. 'Sunbeam Corp. v. Nossoff, 1950-1951 Trade Cas. 64894 (Cal. Super. Ct. 1951) ("compensatory and exemplary damages" measured by difference between fair-trade price and cut price on all known violations). 
punitive damages $;^{141}$ and in a third damages based upon plaintiff's investigative costs and counsel fees.142 Retailers or an association of retailers have never received damages of any sort. While they may be able to show a slackening in sales, estimates of the decrease in business attributable to price reductions by a particular competitor have apparently been unacceptable to the courts. ${ }^{143}$ The causal connection between injury to a manufacturer and the activities of a particular price cutter may be just as difficult to prove. A manufacturer may be successful if he can show that former outlets have discontinued his product in the wake of defendant's price cutting, ${ }^{24}$ but such a clear-cut connection between a loss of sales and price cutting by the.particular defendant will be rare. In addition, the loss of sales to those retailers may be more than offset by increase in sales to price cutters. If the manufacturer's claim is based on injury to his good will or his distribution system, rather than to his sales, no accurate measure of damages is available. As discussed above, it is dubious whether the manufacturer's good will or distribution are damaged at all by price cutting; consequently, proof of such damages will seldom be satisfactory.

\section{CONCLUSION}

Although courts and legislatures have viewed the fair trade laws as primarily for the benefit of manufacturers, ${ }^{145}$ analysis reveals no substantial reasons for manufacturer support of resale price maintenance. ${ }^{110}$ Indeed, with recent developments in retailing methods, the manufacturers' interests are becoming increasingly out of harmony with fair-trade objectives, and a growing number of retailers adamantly oppose a noncompetitive market. ${ }^{137}$ Hence, the principal proponents of fair trade are smaller, higher cost retailers. ${ }^{148}$ But fair trade enforcement by these retailers has been exceedingly difficult.

The federal bill would afford little added protection for them. IVile vastly extending fair trade coverage, it would not provide the means to overcome present obstacles to effective enforcement. The proposed statute would not

141. Sterling Drug, Inc. v. Benatar, 99 Cal. App. 2d 393, 221 P.2d 965 (Dist. Ct. App. 1950).

142. Revlon, Inc. v. Wagonfeld, Trade Reg. Rep. (1959 Trade Cas.) If 69353 (N.Y. Sup. Ct. April 21, 1959).

143. See Weiger 78.

144. See cases cited notes 140-41 supra: cf. Sunbeam Corp. v. Economy Distrib. Co., 131 F. Supp. 791 (E.D. Mich. 1955).

145. See notes 65-66 sipra and accompanying text. State legislatures have also declared the purpose of fair-trade legislation to be the protection of the manufacturer's good will. E.g., MiD. Code ANn. art. 83, \$§ 102-10 (Supp. 1957), Revere Camera Co. v. Masters Mail Order Co., 128 F. Supp. 457 (D. Mrd. 1955) ; N.J. St^т. Axw. $\S 56: 4-3$ (Supp. 1958). But see Frank Fischer Merchandising Corp. v. Ritz Drug Co., 139 N.J. Eq. 105, 19 A.2d 454 (Ct. Err. \& App. 1941).

146. See notes 51-105 supra and accompanying text.

147. See notes 10-11, 20-21 supra and accompanying text.

148. See note 24 supra and accompanying text. 
make injunctions, adequate contempt fines or compensatory damages easier to obtain than under existing legislation. The judicial doctrines of standing, "unclean hands," and judicial reluctance or inability to measure damages have become well-embedded in precedent and would be unaffected by the bill. Nor would access to the federal courts irrespective of diversity jurisdiction ${ }^{140}$ and waiver of jurisdictional amount where "an injunction lies,"150 as provided by the bill, have an impact on these factors, which are as firmly established in the federal courts as in the state courts. Further, limitation of pecuninry awards under the federal bill to "the amount of damage sustained"151 would presumably eliminate any possibility for exemplary damages or an accounting. Only the clause permitting plaintiff to recover reasonable attorney's fees in a successful suit ${ }^{152}$ would ease the financial burden of enforcement. Such reimbursement, however, would only be of minimal assistance to the enforcer since counsel costs may well be insignificant as compared with investigatory expenses. ${ }^{153}$

149. H.R. 1253, 86th Cong., 1st Sess., § 2, p. 7, lines 6-20 (1959).

150. H.R. 1253, sipra note 149 , at 7, lines 6-13.

151. H.R. 1253, supra note 149 , at 7 , lines $10-11$.

152. H.R. 1253, stpra note 149 , at 7 , lines $11-13$.

153. See notes $31-32$ sitpra and accompanying text. 